\title{
Atrioventricular conduction defects in patients presenting with syncope and normal PR interval
}

\author{
P. Touboul and M. Ibrahim ${ }^{1}$ \\ From Hôpital Cardio-Vasculaire et Pneumologique, Lyon, France
}

Ten patients presenting with syncope and a normal $P R$ interval in the standard electrocardiogram were investigated by bundle of His recordings. There was no previous evidence of impaired $A V$ conduction in any of these patients. According to their QRS pattern in the I2 lead electrocardiogram the patients were found to belong to one of three groups: (I) right bundle-branch block with left anterior hemiblock, (2) left bundle-branch block, and (3) normal QRS complex. In all three groups there was prolongation of the HV time indicating a first degree block distal to the His bundle. A bilateral bundle-branch block or a lesion in the main stem of the His bundle was suggested as the underlying cause of the clinical and His bundle electrogram findings. Demand - cardiac pacemakers were implanted in 9 patients. Symptoms of disturbances in consciousness were abolished after cardiac pacing. The value of His bundle recording in the diagnosis of these patients was stressed, and the indications of cardiac pacing were discussed.

High grade or complete AV block is a frequent cause of episodic disturbances of 1 consciousness in elderly subjects. Heart block may be transient or permanent. The early diagnosis of such a condition assumed considerable importance in the last years due to effective pacemaker therapy. Casual electrocardiograms between the syncopal attacks may give a clue to the diagnosis and disclose AV conduction disturbances. Occasionally however the block is intermittent and even - repeated casual tracings reveal only normal conduction. The likelihood that the syncopal attacks are due to intermittent high grade AV block is increased in the presence of QRS contour suggesting a bilateral bundlebranch block (Mahaim, 1931; Blondeau and Lenègre, 1964; Lenègre, 1964, 1966; Langendorf, Pick, and Surawicz, I964; Lepeschkin,

1964; Lasser, Haft, and Friedberg, 1966; Furman et al., 1966). Sometimes even an exhaustive clinical investigation will fail to reveal the underlying disturbances and in such cases one must resort to continuous monitoring to exclude paroxysmal AV block. Though often tedious and costly, this procedure is worth carrying out because of the importance of a correct diagnosis. The introduction of recording of bundle of His electro-

Received 6 March 1972.

1 Present address: Cleveland Clinic, Research Division, Cleveland, Ohio, U.S.A. gram in man (Scherlag et al., 1969; Damato et al., 1969a) have made possible the precise localization of block in the specialized conducting tissue (Damato et al., 1969b; Narula et al., 1970a, 1971; Wit et al., 1970; Schuilenburg and Durrer, I970), AV node, His bundle or bundle-branches. Narula and his coworkers (I97I) have shown that first degree block in any of these regions may be present in spite of a normal PR interval.

In the present study ro patients presenting with syncope and a normal PR interval in the standard electrocardiogram were investigated by His bundle recording. Our aim was to find, through a rapid and easy method, evidence of impaired AV conduction in these patients.

\section{Subjects and method}

The study was carried out on patients admitted to the intensive care unit (during the period from May 1970 till December 1971) because of the history of one or more attacks of syncope. Electrocardiograms available before and at the time of admission were carefully analysed. During their stay in hospital the patients were continuously monitored. Those having abnormal PR prolongation ( $0.21 \mathrm{sec}$ or more) or evidence of second or third degree AV block at any time before the His bundle recording were not included in this work. After being discharged patients were followed up in the pacemaker clinic. Clinical and electrocardiographic findings were noted and compared. 
Procedure The recording of electric activity of bundle of His was made with a 6 French bipolar or tripolar electrode catheter. The catheter was introduced percutaneously by the Seldinger method into the right femoral vein. The investigation was done in the cardiac laboratory in patients who were given a pentobarbitone sodium suppository (120 mg) or an intramuscular injection of diazepam as premedication. A standard lead electrocardiogram was monitored on an oscilloscopic screen. The electrode catheter was advanced under fluoroscopy into the right ventricle, then it was slowly withdrawn across the tricuspid valve until a bi- or triphasic wave occurred between the atrial and ventricular deflections. Intracardiac electrograms were recorded through a preamplifier. Filter frequencies were set at 40 to $700 \mathrm{~Hz}$. All records were made on a multichannel direct recording electrocardiogram by ink jet. The paper speed was 50 or $100 \mathrm{~mm}$, sometimes $200 \mathrm{~mm}$ a second. Careful attention was paid to the grounding of all equipment to avoid the introduction of random currents into the system.

Definition of terms The $R R$ interval is the interval between two consecutive QRS complexes. The PR interval is the interval from the onset of the $P$ wave to the onset of the QRS complex. The $A$ and $V$ complexes are, respectively, the atrial and ventricular electro- grams recorded from the area of AV junction. The $\mathrm{H}$ wave is the bipolar electrogram from the bundle of His. PA time was measured from the onset of $\mathbf{P}$ wave recorded on the standard electrocardiographic lead to the first rapid deflection of the A wave. The AH time is the interval from the first rapid deflection of the $A$ wave to the beginning of the His bundle bipolar electrogram. Since the A wave is recorded from the area adjacent to the AV node, the AH time essentially represents the conduction time through the AV node (Damato et al., 1969a; Narula et al., 1971; Rosen, 1971). The His bundle to ventricular activation (HV) time was measured from the onset of the His bundle deflection to the earliest ventricular depolarization recorded on the intracardiac electrogram or standard leads. It essentially represents the conduction time through the His bundle-branches (Narula et al., 1971; Rosen, 1971). The site of block in these studies has been characterized as occurring proximal or distal to the site of His bundle deflection (proximal or distal to His bundle). It is recognized that block distal or proximal to the site of the recorded His bundle deflection may still be localized in the main bundle. On the basis of previous studies (Damato et al., I969a; Narula et al., 1970a, 1971; Rosen, 197I) in patients with normal AV conduction, the range for normal $\mathrm{PA}$ time $=25$ to $45 \mathrm{msec}$, AH time $=50$ to 120 $\mathrm{msec}$, His bundle duration $=15$ to $20 \mathrm{msec}$, and normal HV time $=35$ to $55 \mathrm{msec}$.

TABLE I Summary of clinical data and follow-up studies

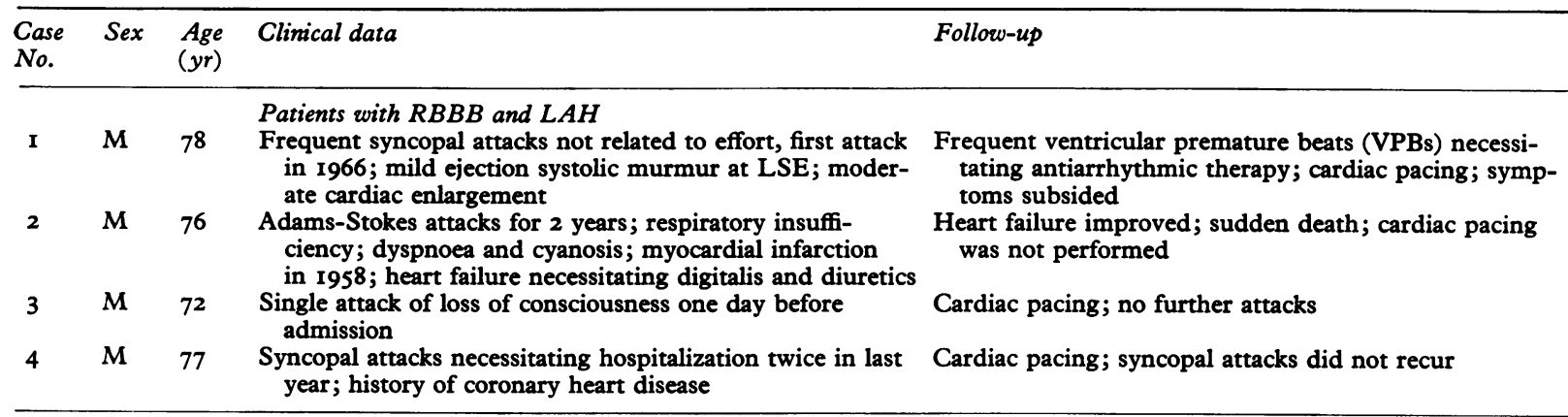

\begin{tabular}{ccccc}
\hline 5 & $M$ & 68 & $\begin{array}{l}\text { Patients with } L B B B \\
\text { Repeated syncopal attacks in the last month; angina of } \\
\text { effort for I year; paroxysms of ventricular tachycardia } \\
\text { reverted by electric shock }\end{array}$ \\
6 & M & 56 & $\begin{array}{c}\text { Frequent Adams-Stokes attacks } 6 \text { months before admis- } \\
\text { sion }\end{array}$ \\
7 & F & 67 & $\begin{array}{c}\text { Repeated attacks of faintness for } 2 \text { years; VPBs; noctur- } \\
\text { nal angina }\end{array}$ \\
8 & M & 45 & $\begin{array}{c}\text { Recurrent syncopal attacks for } 3 \text { years; ECGs showed } \\
\text { LBBB with a normal PR; history of coronary disease; } \\
\text { no improvement with isoprenaline therapy; 4 attacks/ } \\
\text { day in last month }\end{array}$
\end{tabular}

Frequent VPBs in spite of antiarrhythmic drugs; cardiac pacing; disappearance of syncopal attacks

Cardiac pacing; Ist-degree AV block I year later; heart failure; fainting attacks did not recur

Attack of syncope; 2nd-degree AV block; cardiac pacing; fainting attacks did not recur

Cardiac pacing; syncopal attacks did not recur day in last month

$\begin{array}{cccc}9 & \text { F } & 73 & \begin{array}{l}\text { Patients with normal } Q R S \\ \text { Repeated attacks of loss of consciousness for } 2 \text { years; } \\ \text { history of paroxysmal tachycardia; VPBs }\end{array} \\ 10 & M & 58 & \begin{array}{c}\text { Two syncopal attacks in last 15 days; exertional dyspnoea } \\ \text { and fatigue for } 5 \text { months; history of bradycardia }\end{array}\end{array}$

Cardiac pacing; no further attacks

AV block 2nd-degree; cardiac pacing; syncopal attacks subsided 


\section{Results}

The study included 8 men and 2 women, ages ranging from 45 to 78 years with an average age of 67 years. Table I shows a summary of clinical findings and follow-up studies.

Three patients showed later evidence of impaired AV conduction. One developed first degree $\mathrm{AV}$ block one year after His bundle recording (Case 6), the other 2 (Cases 7 and ro) had second degree AV block during their stay in hospital waiting for pacemaker implantation. Demand cardiac pacemakers were implanted in all patients except one (Case 2) who died suddenly. No syncopal attacks occurred after cardiac pacing.

Electrocardiographic findings are presented in Table 2. All patients were in sinus rhythm, heart rate ranging between 62 and 83 beats a minute, with a mean of 73. PR interval ranged between 165 and 205 millisecond ( $\mathrm{msec}$ ), with a mean of $188 \mathrm{msec}$.

Patients were classified into three groups according to the morphology, axis, and duration of QRS complex in the 12 lead electrocardiogram.

Group $A$ : right bundle-branch block with left anterior hemiblock; 4 patients had this pattern (Cases I, 2, 3, and 4) with a mean QRS duration of $146 \mathrm{msec}$ and a mean QRS axis of -75 degrees.

Group B: complete left bundle-branch block; 4 patients had this pattern (Cases 5, 6, 7, and 8) with a mean QRS duration of $136 \mathrm{msec}$ and a mean QRS axis of -24 degrees.

Group C: normal QRS; this group included 2 patients (Cases 9 and 10) with a mean QRS duration of $75 \mathrm{msec}$ and a mean QRS axis of - ro degrees.
Bundle of His studies revealed in all cases an impaired AV conduction. There was an abnormal lengthening of the HV time indicating a first degree block distal to $\mathrm{His}$ bundle (Fig. I to 6).

The HV duration ranged between 60 and $85 \mathrm{msec}$ (mean value $69.5 \mathrm{msec}$ ). His bundle duration was abnormal $(25 \mathrm{msec})$ in a single patient (Case ro). Other components of the PR interval, viz. PA and AH had normal measurements (Table 2).

\section{Discussion}

The introduction of the technique of recording of bundle of His electrogram in man by Scherlag and coworkers in 1969 opened a new field in the study of AV conduction in man. Since that time many reports have been published (Scherlag et al., 1969; Touboul et al., 1971a, b, c; Rosen et al., 197I). Many of these new findings had previously been predicted by physiologists, from standard electrocardiograms and from cardiac pathology (Rosen, 197I). His bundle recording has been extremely useful in discovering the sites of conduction delay in all forms of heart block (Damato et al., 1969b; Narula et al., 1970a, b, 1971; Narula and Samet, 1970; Touboul et al., I97Ib; Rosen et al., 197I). It has been shown that any degree of block may be present in the different regions of the AV conduction system (Narula et al., 1971). We have applied this technique to study a small group of patients presenting with syncope and no previous evidence of impaired AV conduction in the standard electrocardiogram.

Patients were found to belong to one of three groups: (I) patients who had right

TABLE 2 Electrocardiogram and bundle of His studies

\begin{tabular}{|c|c|c|c|c|c|c|c|c|c|}
\hline \multirow{2}{*}{$\begin{array}{l}\text { Case } \\
\text { No. }\end{array}$} & \multirow{2}{*}{$\begin{array}{l}R R \\
(\mathrm{msec})\end{array}$} & \multirow{2}{*}{$\begin{array}{l}P R \\
(m s e c)\end{array}$} & \multicolumn{3}{|l|}{$Q R S$} & \multicolumn{4}{|c|}{ His bundle study } \\
\hline & & & $\begin{array}{l}\text { Duration } \\
\text { (msec) }\end{array}$ & Shape & Axis & $\begin{array}{l}\text { Site of } \\
\text { block }\end{array}$ & $\begin{array}{l}P A \\
(m s e c) \\
(25-45)\end{array}$ & $\begin{array}{l}A H \\
(m s e c) \\
(50-120)\end{array}$ & $\begin{array}{l}H V \\
(m s e c) \\
(35-55)\end{array}$ \\
\hline $\mathbf{I}$ & 720 & $\mathbf{I 7 0}$ & 150 & $\mathbf{R B B B}+\mathrm{LAH}$ & -60 & DH & 35 & 65 & 70 \\
\hline 2 & 960 & 200 & 155 & $\mathbf{R B B B}+\mathrm{LAH}$ & -80 & $\mathrm{DH}$ & 25 & IIO & 65 \\
\hline 3 & 980 & 205 & 135 & RBBB + LAH & -80 & DH & 30 & 105 & 70 \\
\hline 4 & 800 & 200 & 145 & $\mathrm{RBBB}+\mathrm{LAH}$ & -80 & DH & 30 & 105 & 65 \\
\hline 5 & 740 & 200 & 140 & LBBB & -45 & DH & 30 & 100 & 70 \\
\hline .6 & 800 & 190 & 145 & LBBB & -40 & DH & 20 & 100 & 70 \\
\hline 7 & 755 & 190 & 120 & LBBB & -30 & $\mathrm{DH}$ & 25 & 80 & 85 \\
\hline 8 & 780 & 195 & I40 & LBBB & +20 & DH & 30 & 95 & 70 \\
\hline 9 & 800 & 165 & 80 & Normal & -15 & DH & 35 & 70 & 60 \\
\hline 10 & 880 & 165 & 75 & Normal & -5 & DH & 20 & 75 & 70 \\
\hline
\end{tabular}

RBBB + LAH: right bundle-branch block with left anterior hemiblock; DH: distal to His.

LBBB : complete left bundle-branch block. 
bundle-branch block with left anterior hemiblock, (2) patients with left bundle-branch block, and (3) patients with a normal QRS complex. The high incidence of impaired intraventricular conduction in this study is in accord with previous observations (Blondeau and Lenègre, 1964; Lenègre, 1964, 1966; McNally and Benchimol, 1968; Zoob and Smith, 1963; Harris et al., 1965; Lev, 1964; Yater, Cornell, and Clayton, 1936; Rosenbaum, Elizari, and Lazzari, 1970b; Rosenbaum et al., 1970a). It has been shown that about 90 per cent of cases of chronic complete heart block are associated with or related to intraventricular block (Rosenbaum et al., 1970c).

Four patients presented a QRS pattern of right bundle-branch block with left anterior hemiblock. The aetiology, pathology, electrocardiogram, and the significance of such a condition have been the subject of detailed discussions by many authors (Lasser et al., 1966; Rosenbaum et al., 1970b; Watt and Pruitt, 1969; Rothfeld et al., 1969; Blondeau and Lenègre, 1970; Kulbertus and Collignon, 1969). The association of right bundlebranch block with left anterior hemiblock is considered dangerous (Kulbertus and Collignon, 1969). Monitoring of patients with acute septal infarction has revealed that this combination may be followed by complete heart block (Godman, Lassers, and Julian, 1969; Stock and Macken, 1968). AV conduction disturbances were noted in 16.2 per cent of unselected cases (Rosenbaum et al., 1970b). On the other hand chronic complete heart block is preceded by right bundle-branch block with left anterior hemiblock in 40 per cent (Rothfeld et al., 1969) to 59 per cent (Lasser et al., 1966) of the cases. Since this combination of defects implies involvement of two different fascicles of the conduction system, its close relation to the possible occurrence of complete heart block is not unexpected (Rosenbaum et al., 1970b). The development of impairment of AV conduction suggests additional involvement of the posterior division of the left bundle-branch, i.e. intraventricular trifascicular block.

When right bundle-branch block with left anterior hemiblock is associated with an AV delay and a history of fainting spells, complete heart block should be considered imminent and cardiac pacing is indicated.

FIG. 3 Case 5. Left bundle-branch block and a normal PR interval (200 msec). Simultaneous recordings of $I, I I I, V I$, and $H B E$ show HV time prolonged to $70 \mathrm{msec}$.

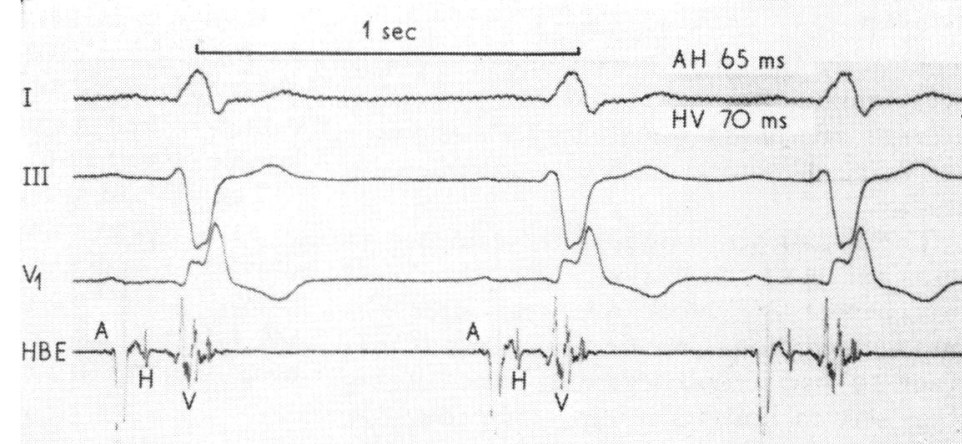

FIG. I Case I: right bundle-branch block and left anterior hemiblock, with normal $P R$ interval ( $170 \mathrm{msec}$ ) but a grossly abnormal $H V$ conduction time (70 msec). Simultaneous recordings of $I, I I I, V_{I}$, and $H B E$.

FIG. 2 Case 7: Left bundle-branch block and a normal PR interval (190 msec). Simultaneous recordings of $I, I I, I I I$, and $H B E$ show a prolonged $\mathrm{HV}$ time $(85 \mathrm{msec})$.
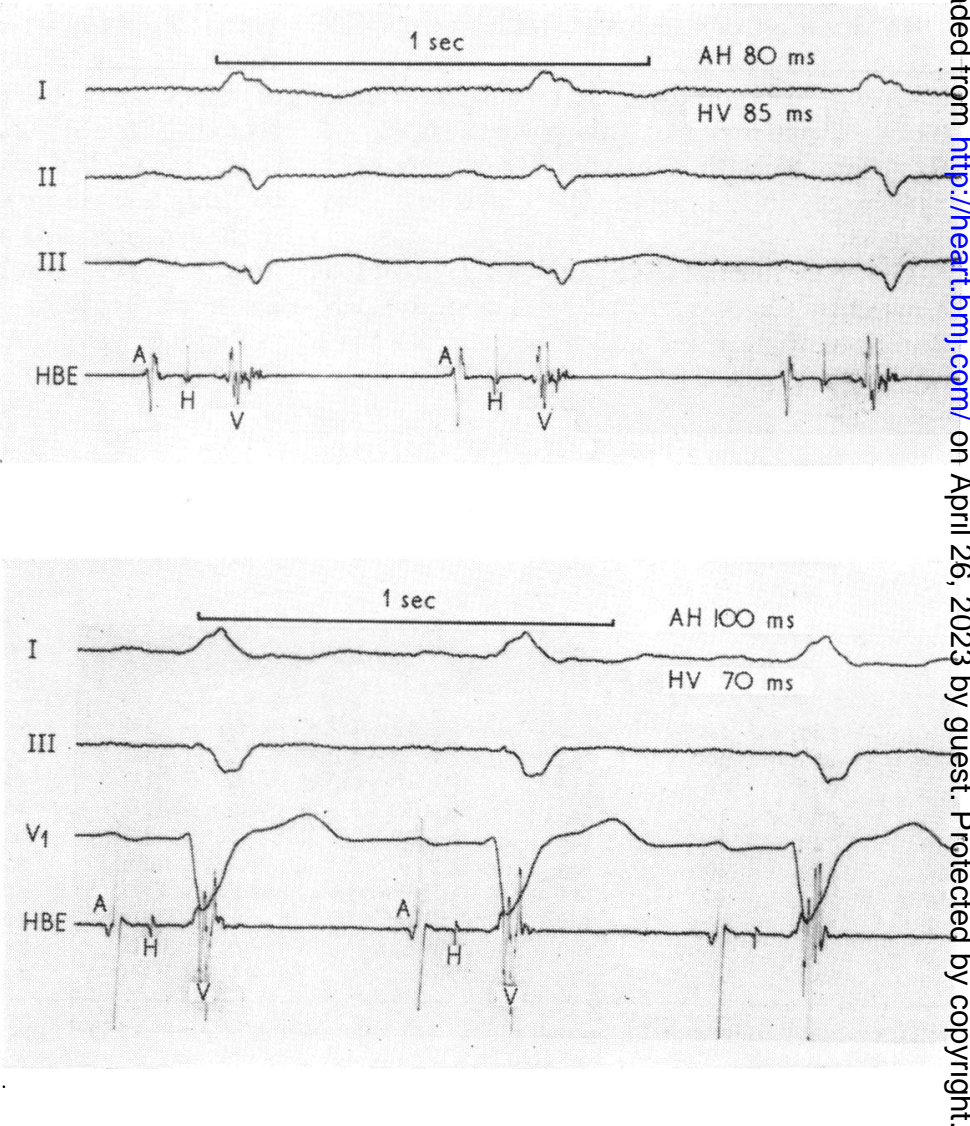
However, it is difficult to predict the outcome of patients showing these abnormalities and a normal AV conduction in the standard electrocardiogram. Present knowledge indicates that about 5 to ro per cent (Rosenbaum et al., I970b, c) of these patients will eventually develop complete heart block. Therefore any indiscriminate tendency to pace all patients is unwarranted. As a guideline Rosenbaum and coworkers (1970b) thought that age might help. Patients over the age of 65 or 70 showing right bundle-branch block with left anterior hemiblock and a normal PR interval probably have Lev's disease and are not expected to develop complete heart block. Conversely patients between 40 and 60 years of age in whom Lenègre's disease is more likely have a greater risk of developing complete heart block.

A better guideline may be the recording of electrograms of the AV conducting fibres. Berkowitz and coworkers (1969), studied His bundle electrograms in 5 patients with right bundle-branch block and left axis deviation and found that $\mathrm{HV}$ time averaged $56 \mathrm{msec}$. In another study on 6 patients with right bundle-branch block and left anterior hemiblock without cardiac infarction Narula and his associates (1969), found that in all patients HV time was abnormal (65 to 75 msec). However, in these studies no mention was made of syncope or heart block. In a recent report on His bundle electrograms in I23 patients Narula and Samet (197I) found that 72 per cent of 68 patients with right bundle-branch block and left axis deviation had an abnormal HV time. ${ }^{1}$ Twelve patients in this group showed second degree AV block or complete heart block for short periods. Of Io patients followed up, 2 developed complete heart block distal to the His bundle deflection. In our study all the patients suffered from attacks of loss of consciousness. Lengthening of the HV interval provided the evidence of a block distal to His bundle (Fig. ( I). One must assume that this was due to a complete block in the right bundle-branch and the anterior division of the left together with a first degree block in the posterior division. However, Narula and Samet (I97I) stated ${ }_{1}^{1}$ Normal values for these authors: 35 to $45 \mathrm{msec}$.

FIG. 6 Case 9. Narrow $Q R S$ complex (80 $\mathrm{msec}$ ) and a normal $P R$ interval ( 165 msec). Simultaneous recordings of I, III, VI, and $H B E$ shows first-degree block distal to His bundle as shown by the abnormal $H V$ time (6o msec).

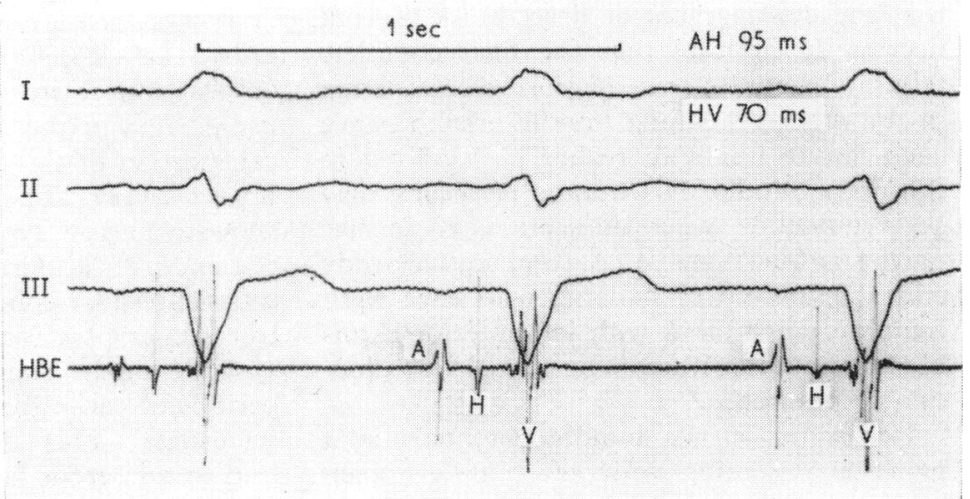

FIG. 4 Case 8. Left bundle-branch block and a normal PR interval (195 $\mathrm{msec})$. $H V$ conduction time is abnormal (70 $\mathrm{msec}$ ) as shown on BHE. Simultaneous recordings of $I, I I, I I I$, and $H B E$.

FIG. 5 Case 10. Narrow $Q R S$ complex (75 msec) and a normal $P R$ interval (165 $\mathrm{msec}$ ). Simultaneous recordings of $I$, III, VI, and $H B E$ show not only that $H V$ time is prolonged ( $70 \mathrm{msec}$ ) but His bundle duration is also abnormal (25 msec). A lesion of the main stem of His bundle is suggested.
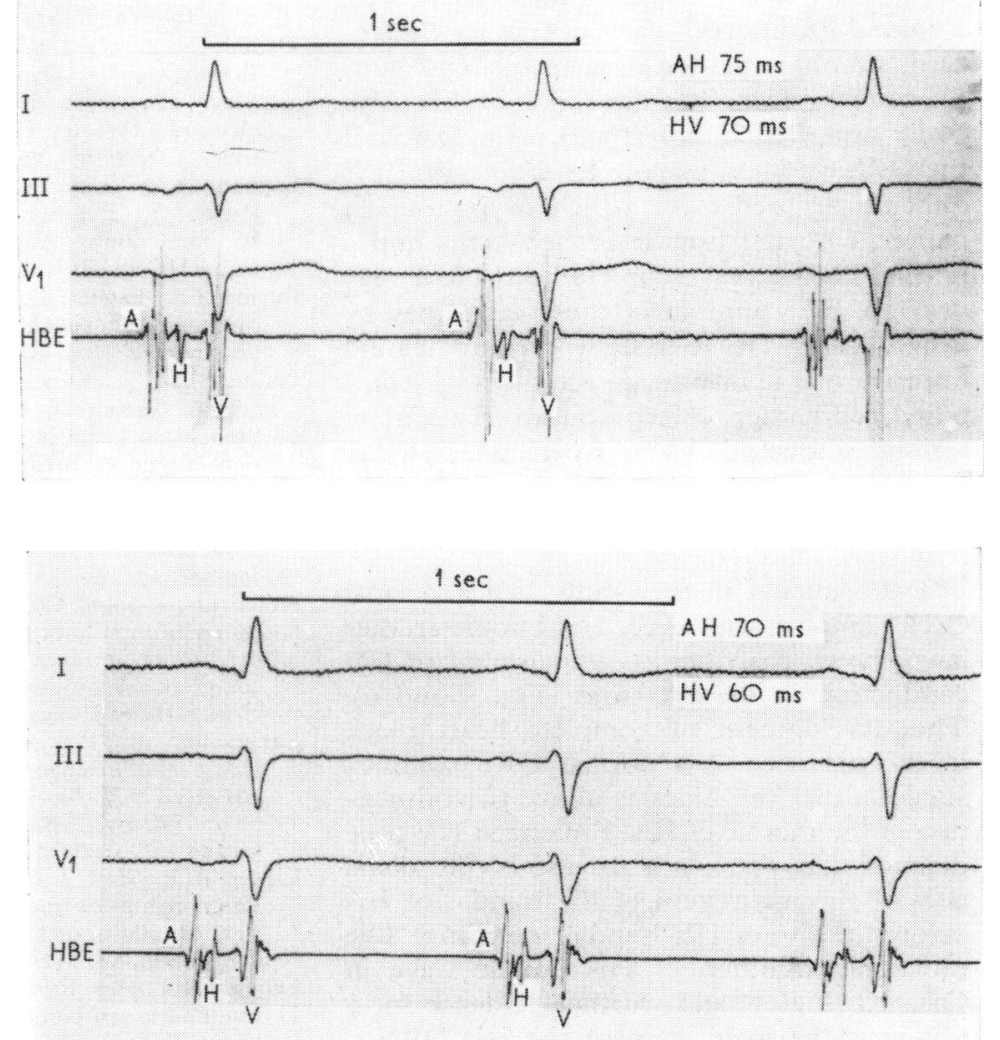
that the development of heart block did not necessarily indicate that the final complete failure of impulse transmission was occurring in the other remaining bundle-branch, since such failure might in reality be localized in the main bundle. His bundle recording may be a guideline when indication of cardiac pacing is questionable. A comparative study and a follow-up of patients who have right bundle-branch block with left anterior hemiblock with and without a normal HV conduction is required.

Recording of His bundle potentials in 4 patients presenting with left bundle-branch block and syncopal attacks revealed AV block distal to His bundle recording (Fig. 2, 3, and 4). Berkowitz and coworkers (1969) recorded His bundle electrograms in 6 patients with left bundle-branch block and found that $\mathrm{HV}$ time averaged $68 \mathrm{msec}$. The authors in this study have not correlated their findings with the development of syncopal attacks or heart block. Previous studies (Rosen et al., 197I; Berkowitz et al., 1969) on patients with left bundle-branch block and first degree AV block in the standard electrocardiogram have shown a significant $\mathrm{HV}$ prolongation and this was considered as a sign of bilateral branch disease. However, the pattern of left bundle-branch block with a normal PR interval is an uncommon electrocardiographic manifestation of bilateral bundle-branch block. The likelihood of this (McNally and Benchimol, I968) is increased if the QRS duration is more than 0.14 sec. It is difficult to predict in which asymptomatic patient with left bundle-branch block and a normal PR interval complete heart block may develop. The number of these cases may be insignificant. His bundle recording should improve our ability to detect them. A combined conduction defect would carry a more serious prognosis. Of our 4 patients, 2 (Cases 6 and 7) developed electrocardiographic evidence of impaired $\mathrm{AV}$ conduction when they were followed up.

Two patients in this study had a normal QRS complex. However, His bundle studies have shown that there is impairment of $\mathrm{HV}$ conduction in these 2 cases (Fig. 5 and 6). The development of complete heart block in the presence of a normal QRS complex suggests that the block is above the bifurcation of the bundle of His. Prolonged HV time denotes that there is a disease of the distal part of the main stem of the bundle of His below the site of His bundle recording. The prolonged duration of His bundle wave in Case ro (Fig. 5) adds further evidence for a lesion in the main stem of the His bundle.
A monofascicular AV block has been described by Rosenbaum and his coworkers (1970a) due to involvement of the penetrating portion of the bundle of His, caused by calcification of the mitral ring or the central fibrous body. The idioventricular rhythm shows a narrow type of QRS complex. The presence of a normal atrioventricular and intraventricular conduction on repeated electrocardiographic recordings in a patient with syncope might suggest a cerebral or other peripheral cause for the disturbance of consciousness. This diagnostic dilemma may lead to numerous laboratory or other useless investigations. His bundle recording is a simple and rapid method to reveal impaired AV conduction. One of our two patients developed second degree AV block when he was followed up later. Implantation of demand cardiac pacemakers in these 2 patients abolished the syncopal attacks.

\section{References}

Berkowitz, W. D., Lau, S. H., Patton, R. D., and Damato, A. N. (1969). His bundle recordings in unilateral and bilateral bundle-branch block (abstract). Circulation, 40, Suppl. III, 44.

Blondeau, M., and Lenègre, J. (1964) Bloc de branche et bloc auriculo-ventriculaire complet. Archives des Maladies du Coeur et des Vaisseaux, 57, 1 .

Blondeau, M., and Lenègre, J. (1970). Bloc Atypique de la Branche Droite. Masson et Cie, Paris.

Damato, A. N., Lau, S. H., Helfant, R. H., Stein, E., Berkowitz, W. D., and Cohen, S. I. (I969a). Study of atrioventricular conduction in man using electrode catheter recordings of His bundle activity. Circulation, 39, 287.

Damato, A. N., Lau, S. H., Helfant, R. H., Stein, E., Patton, R. D., Scherlag, B. J., and Berkowitz, W. D. (1969b). A study of heart block in man using His bundle recordings. Circulation, 39, 297.

Furman, S., Escher, D. J. W., Schwedel, J. B., and Solomon, N. (1966). Transvenous pacing. A seven year review. American Heart fournal, 71, 408.

Godman, M. J., Lassers, B. W., and Julian, D. G. (1969). Pacing in the management of bundlebranch block complicating acute myocardial infarction (abstract). British Heart fournal, 31, 389.

Harris, A., Bluestone, R., Busby, E., Davies, G., Leatham, A., Siddons, H., and Sowton, E. (I965). The management of heart block. British Heart fournal, 27, 469.

Kulbertus, H., and Collignon, P. (1969). Association of right bundle-branch block with left superior or inferior intraventricular block. Its relation to complete heart block and Adams Stokes syndrome. British Heart fournal, 31, 435.

Langendorf, R., Pick, A., and Surawicz, B. (1964). Cause and mechanism of ventricular asystole in advanced AV block. In Sudden Cardiac Death, p. 97. Ed. by B. Surawicz and E. D. Pellegrino. Grune and Stratton, New York.

Lasser, R. P., Haft, J. I., and Friedberg, C. K. (I966). Relationship of marked left axis deviation and right bundle-branch block to heart block (abstract). Circulation, 34, 152.

Lenègre, J. (1964). Etiology and pathology of bilateral bundle-branch block in relation to complete heart block. Progress in Cardiovascular Diseases, 6, 409. 
Lenègre, J. (1966). Bilateral bundle-branch block. Cardiologia, 48, 134.

Lepeschkin, E. (1964). The electrocardiographic diagnosis of bilateral bundle-branch block in relation to heart block. Progress in Cardiovascular Diseases, 6, 445 .

Lev, M. (1964). The normal anatomy of the conduction system in man and its pathology in atrioventricular block. Annals of the New York Academy of Sciences, III, 817.

McNally, E. M., and Benchimol, A. (1968). Medical and physiological considerations in the use of artificial cardiac pacing. Part I. American Heart Fournal, 75, 380 .

Mahaim, I. (I93I). Les Maladies Organiques du Faisceau de His-Tawara. Masson et Cie, Paris.

Narula, O. S., Cohen, L. S., Samet, P., Lister, J. W., Scherlag, B. J., and Hildner, F. J. (I970a). Localization of A-V conduction defects in man by recording of the His bundle electrogram. American fournal of Cardiology, 25, 228.

Narula, O. S., Lister, J. W., Scherlag, B. J., and Samet, P. (1969). Analysis of right bundle-branch block and left axis deviation by His bundle recordings (abstract). Circulation, 40, Suppl. III, 153.

Narula, O. S., and Samet, P. (I970). Wenckebach and Mobitz type II A-V block due to block within the His bundle and bundle branches. Circulation, 41, 947.

Narula, O. S., and Samet, P. (1971). Right bundlebranch block with normal, left or right axis deviation. Analysis by His bundle recordings. American Fournal of Medicine, 51, 432.

Narula, O. S., Scherlag, B. J., Javier, R. P., Hildner, F. J., and Samet, P. (1970b). Analysis of the A-V conduction defect in complete heart block utilizing His bundle electrograms. Circulation, 41, 437.

Narula, O. S., Scherlag, B. J., Samet, P., and Javier, R. P. (1971). Atrioventricular block. Localization and classification by His bundle recordings. American fournal of Medicine, 50, I46.

Rosen, K. M. (197I). The contribution of His bundle recording to the understanding of cardiac conduction in man. Circulation, 43, 961.

Rosen, K. M., Rahimtoola, S. H., Chuquimia, R., Loeb, H. S., and Gunnar, R. M. (I97I). Electrophysiological significance of first degree atrioventricular block with intraventricular conduction disturbance. Circulation, 43, 491.

Rosenbaum, M. B., Elizari, M. V., Kretz, A., and Taratuto, A. L. (I970a). Anatomical basis of A-V conduction disturbances. In Symposium on Cardiac Arrhythmias, p. 147. Ed. by E. Sandoe, E. Flensted-Jensen, and K. H. Olesen. AB Astra, Södertälje, Sweden.

Rosenbaum, M. B., Elizari, M. V., and Lazzari, J. O. (I970b). The Hemiblocks. Oldsmar, Florida. Tampa Tracings.

Rosenbaum, M. B., Elizari, M. V., Lazzari, T. O., Halpern, M. S., and Ryba, D. (1970c). QRS pat- terns heralding the development of complete heart block, with particular emphasis on right bundle-branch block with left posterior hemiblock. In Symposium on Cardiac Arrhythmias, p. 249. Ed. by E. Sandoe, E. Flensted-Jensen, and K. H. Olesen. AB Astra, Söderstälje, Sweden.

Rothfeld, E. L., Zucker, I. R., Tiu, R., and Parsonnet, V. (1969). The electrocardiographic syndrome of superior axis and right bundle-branch block. Diseases of the Chest, 55, 306.

Scherlag, B. J., Lau, S. H., Helfant, R. H., Berkowitz, W. D., Stein, E., and Damato, A. N. (1969). Catheter technique for recording $\mathrm{His}$ bundle activity in man. Circulation, 39, 13.

Schuilenburg, R. M., and Durrer, D. (1970). Observations on atrioventricular conduction in patients with bilateral bundle-branch block. Circulation, 4I, 967 .

Stock, R. J., and Macken, D. L. (1968). Observations on heart block during continuous electrocardiographic monitoring in myocardial infarction. Circulation, 38, 993.

Touboul, P., Clément, C., and Delahaye, J. P. (I971a). L'enregistrement de l'activité électrique du faisceau de His dans le flutter et la fibrillation auriculaire. Coeur et Médecine Interne, ro, 453.

Touboul, P., Clement, C., Delaye, J., Delahaye, J. P., and Gonin, A. (I97Ib). L'enregistrement du potentiel du faisceau de His: une approche nouvelle du diagnostic des blocs de branche bilatéraux. Archives des Maladies du Coeur et des Vaisseaux, 64, 617.

Touboul, P., Clement, C., Roques, J. C., Delahaye, J. P., and Gonin, A. (I97IC). Le syndrôme de Wolff-Parkinson-White. Evidence d'une voie auriculo-ventriculaire accessoire fournie par l'enregistrement du potentiel du faisceau de His. Archives des Maladies du Coeur et des Vaisseaux, 64, 638 .

Watt, T. B., Jr., and Pruitt, R. D. (1969). Character, cause, and consequence of combined left axis deviation and right bundle-branch block in human electrocardiograms. American Heart fournal, 77, 460.

Wit, A. L., Weiss, M. B., Berkowitz, W. D., Rosen, K. M., Steiner, C., and Damato, A. N. (1970). Patterns of atrioventricular conduction in the human heart. Circulation Research, 27, 345.

Yater, W. M., Cornell, V. H., and Clayton, T. (1936). Auriculo-ventricular block due to bilateral bundlebranch lesions: a review of the literature and report of three cases with detailed histopathologie studies. Archives of Internal Medicine, 57, 132.

Zoob, M., and Smith, K. S. (1963). The aetiology of complete heart block. British Medical fournal, 2, II49.

Requests for reprints to Dr. Paul Touboul, Hôpital Cardio-Vasculaire et Pneumologique, 59 Boulevard Pinel, 69 Lyon 3e, France. 